УДК 8

DOI $10.21661 / \mathrm{r}-130242$

\title{
К.А. Оганесян
}

\section{В. БРЮСОВ О ПОЭЗИИ ФРАНЦУЗСКОГО ПОЭТА-СИМВОЛИСТА П. ВЕРЛЕНА НА СТРАНИЦАХ ЖУРНАЛА «ВЕСЫ»}

Аннотация: в статье рассматривается деятельность В. Брюсова в журнале «Весы» в качестве переводчика и критика фаниузского поэта-символиста П. Верлена, творчество которого оказало большое влияние на становление русского символизма.

Ключевые слова: Валерий Яковлевич Брюсов, символизм, франиузская поэзия, Верлен, журнал «Весы».

\section{K.A. Hovhannisyan}

\section{VALERY BRYUSOV ABOUT THE POETRY OF THE FRENCH POET-SYMBOLIST PAUL VERLAINE ON THE PAGES OF THE «VESY» MAGAZINE}

Abstract: the article describes the Valery Bryusov's activity in «Vesy» magazine as a translator and critic of the French poet-symbolist Paul Verlaine. Paul Verlaine's poetry has had an important impact on the Russian symbolism development.

Keywords: Valery Yakovlevich Bryusov, symbolism, French poetry, Verlaine, «Vesy» magazine.

Своеобразен, богат и разносторонен творческий путь В.Я. Брюсова, который еще в молодости обрел известность как один из основоположников декадентской поэзии. Возглавив литературное течение символистов, Брюсов вскоре стал одним из «признанных» мэтров «нового искусства, обрел авторитет и популярность.

Брюсов сравнивает поэтов с первобытным человеком, который создавал слово, чтобы осмыслить новый предмет, а символизм определяет как «поэзию 
оттенков», которая противоположна «прежней поэзии красок». «Поэтому-то истинная поэзия не может не быть искренней. В немногих избранных словах стиха (иногда безсознательно для поэта) затаены самые откровенные признания, раскрыты тайники души» [4, с. 264].

Такими поэтами для Брюсова были Пушкин, Соловьев, Фет и Тютчев, таким он видел и французского поэта Поля Верлена, о котором пишет: «... Когда в наших газетах проскальзывали сведения о новом движении среди поэтов Франции, я с жадностью набрасывался на эти случайные заметки, и первым поэтом, из числа символистов, с которым я познакомился, был Поль Верлен. Правда символизм у него довольно условный, тем не менее и он привел меня в неописуемый восторг» [6, с. 22]. Брюсов считал Верлена во французской литературе первым крупным поэтом-символистом. Из дневниковых записей Брюсова знаем, что он готовился отправить в разные издательства свои переводы Верлена. В это время Брюсов пишет: «Жить еще не живу, хотя собираюсь. Занимаюсь много и начинаю входить в колею. Перевожу довольно удачно Верлена и очень старательно Овидия». В 1894 году Брюсов издал свои переводы верленовских «Романсов без слов».

Одна из первых статей в России о Верлене появилась на страницах журнала «Весы’, который стал самым известным и влиятельным из периодических изданий русских символистов.

Если несомненно то, что «Весы» были главным центром русского символизма, то несомненно и то, что главным вдохновителем его создания и основателем был Брюсов. В своем дневнике он пишет: «Нам разрешили «Весы» и это окончательно нас развело с «Новым Путем». В создании «Весов» Брюсову помогали поэты-символисты Бальмонт и Мережковский, который позже категорически заявлял, что «Весы» - журнал Брюсова» [5, с. 101], и это мнение Мережковского разделяли почти все литераторы того времени: всеми кроме Брюсова, который говорил: «Я не редактор «Весов», но лишь один из ближайших сотрудников журнала» [2, с. 14]. 
Большую роль в «Весах» в течение всех лет его существования играли иностранные корреспонденты. «Весы» стремились к тому, чтобы иметь своих «специальных» представителей-корреспондентов в Париже, Берлине и других крупнейших культурных центах Западной Европы. В этом вопросе «Весам» неоценимую помощь оказывал поэт Максимилиан Волошин, который в это время жил в Париже. Именно с его помощью французский поэт Рене Гиль со временем стал постоянным сотрудником журнала. В 1904-1909 гг. Гиль опубликовал в «Весах» серию обзоров и статей под общим названием «Письма о французской поэзии» и именно Гилем была написана статья о П. Верлене.

Брюсов переводил стихи Верлена (некоторые многократно) почти два десятилетия - с 1892 по 1911г. Если в молодости Брюсов видел в Верлене создателя символизма, то в зрелые годы характеризовал его «как первого во всемирной литературе поэта-импрессиониста» [1, с. 157]. В предисловии ко второму изданию «Французские лирики XIX века» Брюсов признается, что Верлен «чаровал своими песнями», как Орфей: «И этой своей книгой, как и двумя другими, посвященными отдельно Верлену и Верхарну, я надеялся побудить читателей от переводов обратиться к оригиналам» [3, с. 11].

Надо отметить, что в ранних стихотворениях, включенных в сборник «Сатурнические поэмы», таких как «Марко», «Цезарь Борджиа», «Савитри», «Пролог и Эпилог» и особенно в «Смерти Филиппа ІІ» чувствуется влияние как романтиков, так и парнасцев. Изобилие вещей, буйство красок, материальный мир обступают героя, тяготеют над ним. Мы здесь сталкиваемся с подробным и ярким описанием дворца Филиппа II, с красочными портретами цезаря Борджиа и Марко. Тенденцию к «развеществлению» действительности находим во втором сборнике стихотворений Верлена, создававшемся в 1866-1868 гг. и опубликованном в 1989г. под названием «Изысканные празднества». По характеристике Брюсова, это вторая книга Верлена «создавалась под двумя влияниями: книги Гонкуров, посвященной XVIII веку, и открытия в Лувре галереи французских художников той же эпохи». В сборнике наши место такие стихотворения как «На 
прогулке», «На корабле», «Аллея», «Цитера», «Мандолина», «В тиши», «Пантомима»... Отметив, что по цельности композиции - это наиболее законченная книга Верлена, переводчик пишет, что эти стихи как бы переносят в мир поэзии образы Ватто и Буше. В сборнике чувствуется дух итальянской комедии дель арте.

Верлен предпочитает любовь сдержанную, целомудренную, платоническую. Эта особенность верленовского стиха выявляется уже в первом сборнике, в «Сатурнических поэмах», где любимые губы напомнают поэту первые цветы, очаровательный шепот. Верлен рассказывает о боязливых ласках, о душевной чистоте, отвергает «хищную» страсть, трубящую в рог из слоновой кости («Желания»). Здесь же он просит возлюбленную немного умерить свои дикие восторги, убаюкивает ее взглядом. В «Привычной мечте» взгляд возлюбленной напоминает Верлену взгляд статуи. Поэт отмечает ее отдаленность и спокойствие ее голоса. Верлен - символист стремится уничтожить отчетливые границы между душой лирического героя и внешним миром.

Эти тенденции поэта сохраняются в сборнике «Милая песенка», а также в цикле стихотворений «Побежденные». Вместе с тем надо отметить, что в конце 60-х начале 70-х появляются мрачные картины, апокалиптические настроения как, скажем, в стихотворении «Гул полных кабаков» из сборника «Милая песенка»: грязные улицы, людской хаос, утомленный рабочий - такова общая картина города, по которой ходит герой. Это два последних сборника написаны в допереломные в творчестве Верлена годы. Это время, когда поэт во многом близок к традиции своего предшественника - Бодлера, к агрессивности и смелости его поэзии. Эта трансформация очевидна и в общей тональности переводов Брюсова.

В центре верленовкой лирики стоит индивидум и его горькая судьба. Характеризовав «Романсы без слов» как «самый известный» сборник, Брюсов в молодости утверждал также, что это лучшая из книг Верлена, в которой «он стал нако- 
нец самим собой». В переводе этого сборника со всей мощью проявляется мастерство Брюсова - не только и не столько в передаче мыслей и слов французского поэта, сколько верленовского настроения, его печали.

В творческом наследии Верлена особое место занимает книга «Мудрость», над которой автор в основном работал в 1873-1875 гг. и отчасти - во второй половине 70-х. Многие литературоведы Франции этот сборник считают «вершиной» творческого пути поэта. По мнению А. Адама именно в этот период Верленом созданы «самые лучшие его стихи». По мнению критика в 1876-1877 гг. Верлен написал три «великолепных сонета», которые могут фигурировать среди «образцовых» произведений его творчества [7, с. 17].

Надо отметить, что в сборнике «Мудрость» имеются четыре гимна, в которых автор непосредственно обращается к Богу Отцу, Христу-Спасителю и к Богоматери. Из них Брюсов перевел лишь первый (I, «О Боже, ты меня любовью ранил), а о четвертом, названном им «замечательным мистическим диалогом ... между Богом и грешником», заметил: «... я не сумел (и отчасти не посмел) передать его на русском языке». Для образа лирического героя «Мудрости» показательна его апатия и равнодушие ко всему земному, что особенно заметно в III части сборника.

С первой половины 80-х до 1896 года - года смерти - Верлен опубликовал стихотворные сборники «Когда-то и недавно», «Параллельно», в которых нашли место большое количество стихотворений, написанных им в 60-х и 70-х годах. О первом из них Брюсов пишет: «Когда-то и недавно» - одна из интереснейших книг Верлена, и в ней много таких опытов, к которым он не возвращается более никогда». Одновременно в названии сборника переводчик видит глубокомысленную религиозную аллегорию: «Когда-то» - это до обращения, «недавно» после покаяния».

Несомненно, что переводы Брюсовым поэзии Верлена, рассматриваемые многими критиками как «вхождение в символизм», сыграли неоценимую роль как в творчестве самого Брюсова, так и в развитии символизма в России. 


\section{Список литературы}

1. Брюсов В. Из стихов Поля Верлена II // Русская мысль. - 1911. - №2.

2. Брюсов В. Открытое письмо В.Л. Буренину // Новое время. - 1908. - №1.

3. Брюсов В. Полное с/с и переводов. Т. ХXI // Французские лирики XIX века. - СПб.: Сирин, 1913.

4. Брюсов В. Ремесло поэта // Современник. - М., 1981.

5. Мережковский Д. В тихом омуте. - СПб, 1908.

6. «Новости», 18 ноября, 1895г. - фельетон Н. Рока, «Из Москвы»

7. Adam A. Verlaine L'Homme et L'oevre. - 1953.

Оганесян Карина Амаяковна - канд. филол. наук, ассистент кафедры Ереванского государственного университета, Республика Армения, Ереван.

Hovhannisyan Karina Hmayak - candidate of philological sciences, assistant of the Department at the Yerevan State University, the Republic of Armenia, Yerevan. 